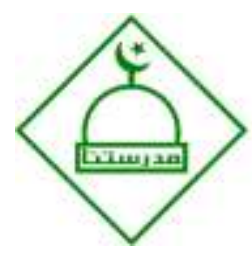

\title{
Teori Belajar Erickson Pada Pembelajaran Kooperatif Tipe Jigsaw Untuk Meningkatkan Motivasi Belajar Peserta Didik Kelas III di SD Muhammadiyah 2 Manado
}

\author{
Fitriani, Maemonah \\ Mahasiswa Program Studi Magister Pendidikan Guru Madrasah Ibtidaiyah UIN Sunan Kalijaga \\ Yogyakarta, Indonesia \\ Dosen Prodi Magister Pendidikan Guru Madrasah Ibtidaiyah Fakultas Ilmu Tarbiyah dan \\ Keguruan UIN Sunan Kalijaga Yogyakarta, Indonesia \\ fitrianifitrianif10@gmail.com,maimunah@uin-suka.ac.id
}

\begin{abstract}
ABSTRAK
Penelitian ini bertujuan untuk meningkatkan motivasi belajar peserta didik.Penelitian ini menggunakan metode eksperimen dengan jenis penelitian kuantitatif. Teknik pengumpulan data yang digunakan yaitu wawancara dan kuesioner, yang subjeknya berupa pendidik dan peserta didik. Analisis data dilakukan dengan reduksi data, display data dan penarikan kesimpulan. Hasil penelitian menunjukkan bahwa dengan menggunakan model kooperatif dalam pembelajaran mampu membuat peserta didik lebih aktif, membangkitkan kerjasama, mengemukakan pendapat dan memberi kesempatan bertanya sehingga peserta didik merasa termotivasi untuk melaksankan pembelajaran disekolah dan dibuktikan dengan hasil sebagai berikut: Aktivitas/Motivasi Siswa $64,28 \%$ dan setelah menggunakan model kooperatif menjadi 92,85\%, dan Rata-rata ketuntasan belajar sebelum menggunakan model kooperatif 70,71, setelah menggunakan model kooperatif 95,71 dan ketuntasan klasikal sebelum menggunakan model kooperatif 64,28\% setelah menggunakan model kooperatif mencapai $92,85 \%$ dari data tersebut menunjukan bahwa penggunaan model kooperatif mampu meningkatkan motivasi peserta didik.
\end{abstract}

Kata-kata Kunci: Teori Belajar, Erickson, Kooperatif, dan Motivasi

\section{Erickson's Learning Theory on Jigsaw Type Cooperative Learning to Improve Learning Motivation of Class III Students at SD Muhammadiyah 2 Manado}

\section{ABSTRACT}

This study aims to increase the learning motivation of students. This study uses an experimental method with quantitative research type. The data collection techniques used were interviews and questionnaires, the subjects of which were educators and students. Data analysis was performed by reducing data, displaying data and drawing conclusions. The results showed that using a cooperative model in learning was able to make students more active, generate cooperation, express opinions and provide opportunities to ask questions so that students feel motivated to carry out learning in school and it is proven by the following results: Activity / Student Motivation 64.28\% and after using the cooperative model it became $92.85 \%$, and the average completeness of learning before using the cooperative model was 70.71, after using the cooperative model 95.71 and classical completeness before using the cooperative model $64.28 \%$ after using the cooperative model reached 92, 85\% of these data indicate that the use of cooperative models can increase student motivation.

Keywords: Learning Theory, Erickson's, Cooperative, and Motivation 


\section{PENDAHULUAN}

Manusia adalah makhluk individual, berbeda antara manusia satu dengan yang lain, karena sifatnya yang individual itulah maka antara manusia saling membutuhkan sehingga sebagai konsukuensinya maka manusia diharuskan menjadi makhluk social. Makhluk yang berinteraksi dengan sesamanya, selain itu manusia memiliki segala potensi, latar belakang, serta cita-cita yang berbeda. Dari adanya perbedaan inilah manusia dapat saling mencerdaskan,atau saling menyayangi. Perbedaan antar manusia satu dengan manusia yang lain yang tidak terkelola dengan baik maka akan terjadi ketersinggungan dan kesalapahaman maka untuk terhindar dari semua itu diperlukan interaksi yang saling tenggang rasa. Dalam dunia pendidikan, khususnya pada jenjang pendidikan formal banyak terdapat perbedaan-perbedaan mulai dari perbedaan suku, agama, gender dll. Dari karakter tersebut, timbul suatu pertanyaan bagaimana guru dapat memotivasi peserta didik untuk saling belajar dan membantu satu sama lain?, bagaimana seorang guru dapat dengan mudah mengorganisasikan kelas sehingga peserta didik saling menjaga satu sama lain, saling mengambil tanggung jawab satu sama lain, dan belajar untuk menghargai satu sama lain terlepas dari suku, tingkat kinerja.

Perkembangan dan kemajuan suatu bangsa itu sangat dipengaruhi oleh mutu pendidikan. Pendidikan yang pada dasarnya merupakan suatu proses untuk membantu manusia dalam mengembangkan dirinya. Untuk meningkatkan mutu suatu pendidikan sangat diperlukan adanya perubahan dibidang pendidikan yaitu dengan cara melalui peningkatan kualitas pembelajaran dengan pembaharuan menggunakan pendekatan ataupun peningkatan relevansi model mengajar. Dan mengajar dikatakan relevan yaitu dengan cara mengantarkan peserta didik untuk mencapai tujuan pendidikan dengan melalui pembelajaran.

Model pembelajaran kooperatif nampaknya merupakan jawaban dari pertanyaanpertanyaan tersebut. Pembelajaran kooperatif adalah kerja kelompok yang terkelola dan terorganisasi sedemikian rupa sehingga peserta didik bekerja sama dengan kelompok kecil untuk mencapai tujuan-tujuan akademik, efektif dan social (Johnson). Dalam model pembelajaran terdapat lima prinsip yang harus tercermin didalamnya. Lima prinsip tersebut adalah 1.Saling ketergantungan positif, 2.Tanggung jawab perseorangan. 3. Tatap muka, 4. Komunikasi antar anggota, 5. Evaluasi proses kelompok.

Demikian juga kepada peserta didik yang belum paham harus meminta penjelasan kepada yang sudah paham. Mereka juga harus berinteraksi satu sama yang lainnya melalui tatap muka dan 
komunikasi. Evaluasi dilakukan baik secara kelompok maupun individual. Prinsip-prinsip pembelajaran yang demikian yang akan menimbulkan kecemasan, kekhawatiran, dan frustasi. Dari uraian itulah Nampak bahwa model pembelajaran kooperatif dapat menjadi solusi dalam mengurangi dampak krisis kepribadian dan mengorganisir pembelajaran untuk mencapai tujuan yang kita inginkan, sebagaimana yang dikemukakan oleh Bern dan Erickson (dalam komalasari, 2010).

\section{METODE PENELITIAN}

Penelitian ini dilakukan di SD Muhammadiyah 2 Manado menggunakan metodeeksperimen karena disekolah ini belum menggunakan model tersebut.Peneliti juga menggunakan data kuantitatif sebagai model dalam pengumpulan data.Data yang peneliti gunakan diperoleh melalui responden yang memberikan pendapat atau persepsi mereka didalam instrument penelitian.Penelitian yang bersifat deskriptif.Sumber data yang diambil oleh peneliti yaitu hasil wawancara peneliti dengan sumber yang diteliti seperti guru dan peserta didik dan kuesioner, Analisis data dilakukan dengan reduksi data, display data dan penarikan kesimpulansubjek peneliti ini adalah peserta didik kelas III SD Muhammadiyah 2 Manado.

\section{HASIL DAN PEMBAHASAN}

\section{A. Teori Belajar Erickson}

Beberapa psikolog ternama menjelaskan tentang perkembangan social anak, di antaranya adalah teori psikososial Erick Erickson. Erick Erickson adalah seorang psikolog asal jerman lahir 15 juni 1902 yang terkenal dengan delapan tahap perkembangan,tahap yang berurutan itu tidak ditetapkan suatu jadwal kronologis yang ketat, Erickson membagi delapan tahap-tahap itu berdasarkan kualitas dasar ego pada tiap individu yaitu:

\begin{tabular}{|c|l|}
\hline No & \multicolumn{1}{|c|}{ Teori Erick Erickson } \\
\hline 1 & Kepercayaaan dasar vs Kecurigaan dasar \\
\hline 2 & Otonomi vs. Perasaan malu dan keragu-raguan \\
\hline 3 & Inisiatif vs. Rasa Bersalah \\
\hline 4 & Kerajinan vs. Inferioritas \\
\hline 5 & Identitas vs Kekacauan Peran \\
\hline 6 & Keintiman vc. Isolasi \\
\hline
\end{tabular}


Teori Belajar Erickson Pada Pembelajaran Kooperatif Tipe Jigsaw Untuk Meningkatkan Motivasi Belajar Peserta Didik Kelas III di SD Muhammadiyah 2 Manado

\begin{tabular}{|l|l|}
\hline 7 & Generativitas vs. Stagnasi Integritas vs. keputusan \\
\hline 8 & Integritas vs Putus Asa \\
& \\
\hline
\end{tabular}

psikososial merupakan perkembangan teori psikoanalisis Sigmun Freud. Psikososial merupakan teori yang membahas tentang perkembangan individu terjadi selama hidupnya dibentuk oleh lingkungan seperti berfikir, bereaksi, saling mempengaruhi dengan yang lainnya.

Teori perkembangan 8 tahap Erickson menggambarkan pertumbuhan dan perubahan sepanjang hidup, dengan fokus pada interaksi sosial dan konflik yang muncul selama berbagai tahap perkembangan.Dalam setiap tahap, orang dihadapkan pada konflik pembangun yang berdampak pada fungsi dan pertumbuhan selanjutnya.

Menurut erickson, proses perkembangan dikuasai oleh kekuatan-kekuatan lingkungan dan sosial, Erickson menyatakan bahwa dalam perkembangan manusia diliputi serentetan konflik yang harus ditanggulangi setiap orang. Erickson percaya bahwa ego harus menggabungkan cara penyesuaian diri dengan cara penyesuaian diri yang salah. Sebagai contoh pada tahap pertama perkembangan psikososial. Kita dapat merespon krisis dengan mengembangkan salah satu kepercayaan atau ketidak percayaan. Dengan kepercayaan akan lebih menyesuaikan diri dan merupakan cara yang di inginkan, hal itu jelas merupakan sikap psikologis yang lebih sehat. Setiap orang juga harus mengembangkan sikap ketidak percayaan pada beberapa tingkatan sebagai bentuk perlindungan. Selanjutnya otonomi lawan keraguan; inisiatif lawan kesalahan; ketekunan lawan kelemahan; koheksi identitas lawan kebimbangan peran; keakraban lawan isolasi, semua itu dikembangkan pada sikap sosial. Karena erickson percaya bahwa interaksi sosial dan pengalaman memainkan peran yang menentukan.

Berdasarkan uraian teori psikososial, perkembangan seorang anak tidak pernah terlepas dari lingkungan social seperti lingkungan social primer yaitu keluarga dan lingkungan social sekunder yaitu kelompok bermain, dan sekolah, sebagaimana pada teori belajar menurut Bern dan Erickson (2001;5) “Cooperatif Learning (pembelajaran kooperatif) meupakan strategi pembelajaran dengan cara berkelompok belajar kecil dimana peserta didik bekerja sama untuk mencapai sebuah tujuan belajar"

Pembelajaran kooperatif memiliki basis pada teori pembelajaran social (Arends, 1997). Fokus utama dalam pembelajaran kooperatif adalah tidak hanya bertumpu pada apa yang dilakukan 
peserta didik melainkan pada apa yang dipikirkan peserta didik selama proses pembelajaran berlangsung. Dalam model pembelajaran kooperatif, guru berperan sebagai fasilitator, penyedia sumber belajar peserta didik, sebagai pembimbing dalam belajar kelompok dan sebagai pemberi motivasi dalam proses pembelajaran.

Erikson dalam seifert (1991) memberikan alternative bagaimana mewujudkan pembelajaran yang sempurna sesuai tujuan yang ingin kita capai, yaitu dengan cara:

1. Berikan tugas dan aktifitas yang peserta didik inginkan dan yang dapat dikerjakan peserta didik.

2. Tingkatkan semangatnya dengan cara mengurangi tingkat kompetensi juga beri keyakinan bahwa setiap peserta didik mampu menyelesaikannya.

3. Kuatkan usaha dan ketekunannya.

4. Bantu peserta didik yang mengalami kesulitan sehingga peserta didik tidak mengalami kesulitan.

\section{B. Pembelajaran Kooperatif}

Pembelajaran kooperatif merupakan pembelajaran yang dilakukan secara berkelompok.Pembelajaran kooperatif sangat jauh berbeda dengan pembelajaran yang konvensional yang bersifat tertutup karena kurang perhatian dengan yang lainnya. Prinsip dalam pembelajaran kooperatif ialah pemanfaatan kelompok kecil yang dimana peserta didik dapat bekerjasama dalam

kelompok-kelompok kecil yang memungkinkan peserta didik dapat mengoptimalkan pembelajaran kooperatif untuk memaksimalkan belajar anggota lain dalam kelompok masingmasing.

Oleh karena itu setiap peserta didik harus mendorong atau terdorong untuk melakukan keinginan belajar dalam kelompok, kegiatan pembelajaran kooperatif yang dibangun atas kerja sama dan saling pengertian membantu satu sama lainnya. Bekerjasama dalam memaksimalkan proses pembelajaran kooperatif dengan peserta yang lainnya.

Pembelajaran kooperatif merupakan salah satu bentuk pembelajaran berdasarkan paham kontruktivis yang mana artinya bahwa teori pembelajaran memandu pengembangan model dan perancangan stategi pembelajaran. Teori kontrukstivisme sosial Vygotsky dalam bukunya schunk 
(2012;274) yang terkenal dengan istilah teori sosiokultural vygotsky yang menekankan pada lingkungan social sebagai fasilitator pembangunan dan juga pembelajaran.

Pembelajaran kooperatif merupakan strategi belajar dengan sejumlah peserta didik sebagai anggota kelompok kecil yang tingkat kemampuan anggotanya berbeda-beda.Model pembelajaran kooperatif ini dibentuk dalam kelompok kecil antara 4-6 peserta didik sebagai bentuk aktivitas belajar dan bekerja secara kolaboratif.

Pembelajaran kooperatif merupakan strategi belajar dengan sejumlah peserta didik sebagai anggota kelompok kecil yang tingkat kemampuan anggotanya berbeda-beda. Model pembelajaran kooperatif ini dibentuk dalam kelompok kecil antara 4-6 peserta didik sebagai bentuk aktivitas belajar dan bekerja secara kolaboratif.

Pembelajaran kooperatif dikatakan sebagai salah satu pendekatan kontruktivisme berdasarkan teori bahwa peserta didik akan lebih mudah menemukan dan memahami konsep yang sulit jika mereka bisa berbicara antara satu dengan yang lainnya mengenai soal tersebut. Dalam pelaksanaannya, model pembelajaran kooperatif ada empat unsur penting, yaitu:

1. Adanya peserta dalam kelompok.

2. Adanya aturan kelompok

3. Adanya upaya belajar setiap anggota kelompok.

4. Adanya tujuan yang harus dicapai.

5. Motivasi belajar

\section{Pembelajaran kooperatif tipe Jigsaw}

Pembelajaran kooperatif tipe jigsaw merupakan pembelajaran yang dimana peserta didik belajar didalam kelompok-kelompok dan harus bertanggung jawab atas penguasaan materi belajar yang sudah diberikan oleh guru kepada kelompok lain.

Jigsaw pertama kali dikembangkan dan diujicobakan oleh Elliot Aronson dan teman-teman di Universitas Texas, kemudian diadaptasikan oleh Slavin dan temen-teman di Universitas John Hopkins (Arends, 2001). 
Pembelajaran kooperatif tipe jigsaw dikembangkan oleh Aronson et.al. sebagai model pembelajaran cooperatif learning. Pembelajaran kooperatif tipe jigsaw ini pun bisa digunakan pada fokus pembelajaran membaca dan menulis.

Teknik ini dengan cara guru memperhatikanpengalaman peserta didik dan mengajarkan bahwa pengalaman ini harus dikembangkan dan dijadikan pengalaman. Dan juga peserta didik diberi ketrampilan untuk saling gotong royong bersama teman-teman kelompoknya agar tercipta empati pada setiap diri peserta didik.

Dalam pembelajaran kooperatif tipe jigsaw terdiri dari beberapa anggota kelompok yang harus bertanggung jawab atas penguasaan materi untuk diajarkan lagi pada kelompok lainnya.

Model pembelajaran tipe jigsaw merupakan model kooperatif yang beranggota 4-6 orang peserta didik secara bekerja sama saling ketergantungan dan bertanggung jawab atas ketuntasan bagian materi pelajaran yang harus dipelajari dan menyampaikan materi tersebut kepada kelompok lain.

Pembelajaran kooperatif tipe jigsaw dirancang untuk meningkatkan rasa tanggung jawab peserta didik terhadap pembelajarannya sendiri dan pembelajaran orang lain. Peserta didik bukan saja mempelajari materi yang diberikan dan mengajarkan materi yang diberikan kepada anggota kelompok lain. Hal itu agar peserta didik saling bergantung satu dengan yang lain dan harus bekerja sama secara kooperatif.

Para anggota dari tim - tim yang berbeda dengan topik yang sama bertemu untuk diskusi (tim ahli) saling membantu satu sama lain tentang topik pembelajaran yang ditugaskan kepada mereka. Kemudian siswa-siswi itu kembali pada tim / kelompok asal untuk menjelaskan kepada anggota kelompok yang lain tentang apa yang telah mereka pelajari sebelumnya pada tim ahli.

Pembelajaran kooperatif tipe jigsaw sendiri proses pembelajarannya yaitu dengan cara dalam satu kelompok, tiap-tiap kelompok. Jadi tiap kelompok terdapat kelompok asal dan kelompok ahli. Kelompok asal yaitu kelompok induk peserta didik yang beranggotakan peserta didik dengan kemampuan, asal dan latar belakang keluarga yangberbeda.

\section{Motivasi Belajar}

Motivasi belajar adalah suatu daya penggerak baik yang berasal dari individu maupun yang berasal dari luar individu yang mendorong seseorang untuk melaksanakan aktivitas untun 
mencapai suatu tujuan yang diharapkan. Indikatornya merupakan durasi kegiatan, keuletan, target, cita-cita, arah sikap dan tujuan.

Dalam proses pembelajaran, model pembelajaran mempunyai peran yang sangat penting. Melalui model pembelajaran tujuan pembelajaran akan tercapai dengan baik, karena model pembelajaran sangat mempengaruhi proses belajar, seperti halnya belajar yang monoton/ceramah yang dilakukan di SDN 09 manado tepatnya di kelas III dimana proses pembelajaran hanya dengan ceramah sangat membosankan bagi peserta didik, apalagi pada peserta didik usia sekolah dasar yang dimana mereka akan lebih cepat paham jika mereka ikut andil dalam pembelajaran/berperan seperti pada model kooperatif yang dimana peserta didik merasa ikut andil dalam pembelajaran sehingga mereka merasa lebih bergairah dalam belajar karena dalam penerapannya pembelajaran yang hanya dengan ceramah sangat membuat peserta didik merasa jenuh, tidak bersemangat, bahkan ada juga yang sibuk ngobrol dengan teman sebangkunya, tentu hal ini membuat peserta didik tidak paham apa yang sedang guru jelaskan dan menyebabkan hasil belajar menurun.untuk menciptakan pembelajaran yang efisien maka dalam sebuah pembelajaran dibutuhkan model pembelajaran yang menarik motivasi peserta didik dan pembelajaran kooperatif merupakan solusi yang sangat tepat digunakan untuk mewujudkan pembelajaran yang menyenangkan dan menimbulkan motivasi dalam belajar.

Target dalam penelitian ini adalah wali kelas III bu Ais Ahmad dan siswa kelas III sekolah dasar Muhammadiyah 2 Manado. Adapun data dari pertanyaan yang di lontarkan adalah sebagai berikut Hambatan yang di alami oleh guru adalah memakan waktu yang lama dan kurangmya perhatian dari kepala sekolah untuk menerapkan model pembelajaran atau media, berikut ini merupakan perbandingan secara keseluruhan mengenai pembelajaran dengan menggunakan model kooperatif sebelum dan sesudah:

\section{Tabel 1}

Hasil Pembelajaran sebelum dan sesudah penggunaan model kooperatif

\begin{tabular}{|c|c|c|}
\hline Keterangan & sebelum & sesudah \\
\hline Akivitas Siswa/Motivasi & $64,28 \%$ & $92,85 \%$ \\
\hline Rata-rata ketuntasan belajar & 70,71 & 95,71 \\
\hline Ketuntasan klasikal & & \\
\hline
\end{tabular}


Dari data tabel diatas terlihat jelas bahwa dari sebelum menggunakan model kooperatif Aktivitas/Motivasi Siswa 64,28\% dan setelah menggunakan model kooperatif menjadi 92,85\%, dan Rata-rata ketuntasan belajar sebelum menggunakan model kooperatif 70,71 setelah menggunakan model kooperatif 95,71 dan ketuntasan klasikal sebelum menggunakan model kooperatif 64,28\% setelah menggunakan model kooperatif mencapai 92,85\%.

\section{SIMPULAN}

setelah melakukan penelitian kualitatif yang dilakukan dengan diterapkannya penggunaan model pembelajaran kooperatif, maka dapat disimpulkan bahwa adanya peningkatan terhadap motivasi peserta didik kelas III SD muhammadiyah 2 Manado. Dari hasil penelitian yang diperoleh dan dibuktikan dengan meningkatnya motivasi belajar selama pembelajaran berlangsung dimana peserta didik lebih fokus dalam menerima dan memahami materi, selalu berpartisipasi dalam kelompok, aktif dalam menyelesaikan tugas sesuai waktu yang diberikan.

Isi dari simpulan hendaknya merupakan jawaban atas pertanyaan dan tujuan penelitian.Simpulan dipaparkan dalam satu paragraf, bukan point-point, dan diungkapkan bukan dalam kalimat statistik. Simpulan dilengkapi dengan satu paragraf saran hasil penelitian.

\section{DAFTAR PUSTAKA (Garamond 12, ditebalkan)}

Febyanto Chandy, (april 2016). Analisis Pengaruh Kelompok social dan Keluarga Terhadap Perkembangan Psikososial Anak (Studi kasus Pada Siswa SDN Wonokerto 01 kabupaten malang. Jurnal Pendidikan Dasar Nusantara, Vol 2, No 1.

Krismawati Yeni, (oktober, 2014) Teori Psikologi Perkembangan Erick Erickson dan Manfaatnya Bagi Tugas Pendidikan Kristen Dewasa Ini. Jurnal Teologi dan Pendidikan Agama Kristen, Vol 2, No 1.

Lase Sadiane, (April 2018) Pembelajaran Kooperatif Dalam Pengembangan Sikap pada tugas Akademik. Jurnal warta;Ed 48.

Rosyidin Ummi, (Desember 2016) Pengaruh Model Pembelajaran Kooperatif Tipe Jigsaw Terhadap Hasil Belajar Matematika Siswa Kelas VIII SMP, Vol 1, No 2.

Sjafeti Irna, (2017) Pembelajaran Kooperatif Dalam Pengembangan Sikap Pada Tugas Akademik. Jurnal Educate, Vol 2, No 1.

Sulistyo Ignatius, (2016) Peningkatan Motivasi Belajar Dengan Menerapkan Model Pembelajarn Kooperatif Pada Pelajaran PKN. Jurnal Studi Sosial, Vol 4, No 1.

Oktaria Renti, (Juli 2016) Implementasi Pendekatan Pembelajaran Dalam Pendidikan Anak Usia Dini. Jurnal NIZHAM, Vol 01, No 02. 